Ana Dili Eğitimi Dergisi
www.anadiliegitimi.com
Gönderilme:22.05.2015 / Kabul Edilme:22.07.2015

\title{
Derin Yapı Yüzey Yapı Illişkisi Bağlamında Temel Dil Becerileri Üzerine Bir Analiz Çalışması
}

\author{
Bilginer ONAN $N^{1}$
}

\begin{abstract}
Öz
Bu çalışmada, derin yapı yüzey yapı ilişkileri bağlamında, ana dili eğitiminde temel dil becerileri olarak kabul edilen dinleme, konuşma, okuma ve yazma kavramları analiz edilmiştir. Birinci bölümde, ilk kez Port Royal Gramer Okulu tarafından ortaya konan ve 1960'larda Noam Chomsky tarafından Üretimci Dönüşümsel Dil Bilgisi kuramıyla tekrar gündeme getirilen derin yapı ve yüzey yapı kavramları hakkında bilgi verilmiştir. Çalışmanın ikinci bölümünde ise derin yapı ve yüzey yapı ilişkileri çerçevesinde dinleme, konuşma, okuma ve yazma becerileri analiz edilmiştir. Çalışmanın amacı, dilin iki temel boyutu olan anlam ve biçim ilişkileri bağlamında, temel dil becerilerinin eğitimi sürecinde belirleyici olan unsurları tespit ederek, sürecin programlanmasına yönelik öneriler geliştirmektir. Çalışma çerçevesinde yapılan analizlerde boğumlama, bürün olguları, beden dili, üretici kelime hazinesi, alıc kelime hazinesi, akıcılık, metin türü, yazım ve noktalama, bağdaşıklık, tutarlıık, ön bilgi, kelime tanıma, kelime ayırt etme, edinilmiş bilgi, önvarsayım, sezdirim kavramlarının derin yapı yüzey yapı ilişkileri bağlamında temel dil becerilerinin geliştirilmesinde süreci etkileyen unsurlar olduğu tespit edilmiştir. Bu kavramlar arasında boğumlama, bürün olgusu, beden dili, akııılık, bağdaşıklık, metin türü, kelime tanıma, kelime ayırt etme, yazım ve noktalama, doğrudan yüzey yapıyla ilgilidir. Üretici kelime hazinesi, akıcılık, alıcı kelime hazinesi, tutarlılık, ön bilgi, edinilmiş bilgi, önvarsayım ve sezdirim kavramları ise derin yapıyı ilgilendirmektedir. Akıcılık kavramının bütün dil becerileriyle ilgili olduğu belirlenmiştir.
\end{abstract}

Anahtar Kelimeler: Derin yapı, yüzey yapı, Türkçe eğitimi, temel dil becerisi.

\section{An Analysis Study on Basic Language Skills in Regard to the Relationship of Deep Structure and Surface Structure}

\begin{abstract}
This study examines the concepts of speaking, writing, reading and listening called as basic language skills in mother tongue education in regard to the relationship of deep structure and surface structure. The first chapter provides information on the concepts of deep structure and surface structure originally developed by Port Royal Grammar School and brought to the agenda by the theory of Transformational Generative Grammar put forward by Noam Chomsky in 1960s. The second chapter analysed the skills of speaking, writing, reading and listening in the context of the relationship of deep structure and surface structure. The purpose of the study is to determine the decisive elements in the process of the training of basic language skills within the context of meaning and form relationships, which are two fundamental dimensions of the language, and to develop proposals for scheduling the process. In the analyses of the study, it has been revealed that the concepts of articulation, prosody phenomena, body language, productive vocabulary, receptive vocabulary, fluency, text type, spelling and punctuation, coherence, consistency, prior knowledge, word recognition, word discrimination ability, acquired knowledge, presupposition, implication are the elements that have an impact on the development of basic language skills within the context of deep structure and surface structure relationships. The
\end{abstract}

\footnotetext{
${ }^{1}$ Doç.Dr., Mustafa Kemal Üniversitesi Eğitim Fakültesi Türkçe Eğitimi Bölümü. Antakya.

e- posta:bilgineronan@gmail.com
} 
concepts of articulation, prosody phenomena, body language, fluency, coherence, text type, word recognition, word discrimination ability, spelling and punctuation are directly linked to surface structure. On the other hand, the concepts of productive vocabulary, receptive vocabulary, consistency, prior knowledge, acquired knowledge, presupposition and implication are related to deep structure. It has been determined that the concept of fluency is related to all language skills.

Keywords: Deep structure, surface structure, Turkish education, basic language skill.

\section{Derin Yapı ve Yüzey Yapı Kavramları}

Dil göstergesi, anlam ve biçim olmak üzere iki temel unsurdan meydana gelmektedir. Dil çalışmaları tarihine bakıldığında, bu katmanların 17. yüzyıla kadar terimleşmedikleri görülmektedir. İlk kez 17. yüzyılda Port Royal Okulu tarafından ortaya konan derin yapı ve yüzey yapı kavramları, anlam ve biçim olarak söz dizimi yapısının iki temel katmanını oluşturmaktadır. "Derin yapı yüzey yapı kavramları, daha sonraları, 1965 yılında Üretici -Dönüşümsel Dilbilgisinin ikinci aşaması olan Standart Kuram çerçevesinde Noam Chomsky tarafından gündeme getirilmiştir. Genişletilmiş kuramda, edim ve edinç kavramları da açıklanmıştır" (Rifat, 1998: 74). Dilbilim literatüründe, derin yapı ve yüzey yapı ile ilgili şu bilgiler verilmektedir.

Derin yapı, "yüzey yapının karşıt durumu olup, bir cümlenin soyut olarak anlam bilimsel boyutunu temsil etmektedir. Bu yapı, cümlenin biçimsel veya sentaktik görüntüsünün aksine, görünmeyen fakat algılanabilen seviyesi olup dönüşümlü gramerde temel yapı, uzak yapı, birincil yapı vb. birçok adla ifade edilmektedir. Cümlenin bu seviyesi bize aynı yüzey yapıya sahip cümlelerin derinlerinde yatan farklı anlamları ayırt etmemiz konusunda yardımcı olmaktadır" (Demirci, 2013: 70).

Vardar (1998:73)’a göre derin yapı, “Üretici - Dönüşümsel Dilbilgisinde, sözdizimsel bileşende elde edilen, evrensel nitelikli olduğu varsayılan biçimsel soyut tümce yapısıdır. Bir tümcenin dönüşümsel süreç öncesindeki derin yapısı, o tümcenin anlamını belirlemektedir."

Kıran (2001: 159)'a göre derin yapı, “dönüşüm işlemlerinden önceki gerçekleşmemiş, henüz sese, sözcüğe dökülmemiş olduğu için soyut bir yapıdır. Derin yapı katmanındaki anlam ögeleri, dönüşüm işlemleri sonunda belli bir dile özgü ses, biçimbilim, söz dizimi kurallarının işlenmesiyle somutlaşarak gerçeklik kazanır. Başka bir deyişle yüzey yapıya kavuşurlar. Kısacası, dönüşüm işlemleri sayesinde yüzey yapıya doğru çıkarak görünür duruma gelirler."

Rifat (1998: 74)’a göre derin yapı “Bir tümcenin dönüşüm kuralları uygulanmadan önceki soyut yapısıdır. Söz dizimsel bileşende, tabanın kurallarıyla elde edilen bu soyut yapı, tümcenin anlamını belirler. Derin yapı, taban bileşeninde ortaya çıkar. Taban bileşeni, çok sayıda derin yapı üretir." 
Yüzey yapı, "bir cümlenin sentaktik olarak üretilmiş ve son hâlini almış şeklidir. Yüzey yapıdaki cümleler, nihaî olarak ifade edilmiş olup duyulmaya (kulağa) ve okunmaya (göze) hitap eder, duruma gelmişlerdir" (Demirci, 2013:70).

Rifat (1998:74)’a göre yüzey yapı “derin yapıların dönüşüm denilen işlemlerle bir üst katmana, daha az soyut bir düzleme aktarılması sonucunda doğar. Bir dilde, aynı derin yapıdan türeyen çok çeşitli düzey yapılar vardır."

Vardar (1998: 235)’a göre yüzey yapı “Üretici - Dönüşümsel Dilbilgisinde, derin yapı biçimlerine uygulanan dönüşümler sonucu gerçekleştirilen bildirişime elverişli duruma gelen tümce biçimidir."

Derin yapı, anlamın tözünü temsil eden yapıdır. Töz niteliğindeki anlam, soyut bir nitelik taşımaktadır. Töz niteliğindeki bu soyut anlam, yüzey yapıya dönüşerek somut nitelikli, sınırları belirlenmiş ve töz niteliğinden uzaklaşmış anlamı oluşturur. Töz nitelikli anlam, derin yapıda evrensel bir nitelik taşımaktadır. Bu evrensel nitelik, yüzey yapıda kaybolmaktadır. Dünya üzerindeki dilleri birbirinden farklı kılan özelliklerin başında, yüzey yapı gelmektedir. Her dil, evrensel nitelikli derin yapıyı kendi özellikleri ve kuralları çerçevesinde yüzey yapıya dönüştürmektedir. Kısaca, derin yapı evrensel bir nitelik taşımaktadır.

Bir dilin, yüzey yapısını oluşturan özellikler, o dilin gramer kurallarını meydana getirmektedir. Ses birimden söz dizimsel yapıya kadar bütün özellikler dile özgüdür. Bir dili öğrenme sürecinde sadece yüzey yapı kurallarına odaklanmak yeterli değildir. Derin yapı yüzey yapı ilişkilerinde de bir eşgüdümün sağlanması gerekmektedir. Dil öğrenme sürecini etkileyen faktörler, bu ilişkiler bağlamında değerlendirilmelidir.

\section{Derin Yapı ve Yüzey Yapı ilişsisi Bağlamında Temel Dil Becerilerinin Analizi}

Dil becerilerine geçmeden önce, genel anlamıyla beceri kavramı üzerinde durmak gerekiyor. Beceri, "doğrudan gözlenebilen veya gözlenemeyen zihinsel yeterlilikler olarak tanımlanmaktadır. Becerinin gözlenebilirlik niteliği esas alındığında, karşımıza üç temel bileşen çıkmaktadır. Bunlar; bilgi, uygulama ve iş yapma bileşenleridir" (Güneş, 2007: 57). Türkçe öğretiminde dil becerisi dendiğinde, aynı zamanda, birer öğrenme alanı olarak tanımlanan dilin okuma, dinleme, konuşma ve yazma süreçlerindeki yeterlilikleri akla gelmelidir. Bir öğrencinin okuma, dinleme, konuşma ve yazma becerilerindeki yeterliliği, dili kullanma becerisinin göstergesidir. Dil öğretiminin temel hedeflerinden biri, öğrencilerin dört temel dil becerisini geliştirmektir. Okuma, konuşma, yazma ve dinleme olarak belirlenen temel dil becerileri, kendi içerisinde anlama becerileri ve anlatma becerileri; yazılı dil becerileri ve sözlü dil becerileri olmak üzere dört alt gruba ayrılmaktadır. 


\section{Derin Yapı ve Yüzey Yapı İlişkisi Bağlamında Konuşma Eğitimi}

Konuşma, anlatıma dayalı bir dil becerisi olup sözlü dil grubuna girmektedir. Konuşma becerisi, ses tözünü doğrudan kullandığı için sözlü dil becerisi olarak da tanımlanmaktadır. Doğuştan getirilen ve edinim süreci içerisinde sosyal çevrede kazanılan bir yetidir. En genel tanımıyla, "bir insanın başka bir insana ya da topluluğa, duygu ve düşüncelerini sözle anlatmasıdır" (Önen, 2004: 27). Bireysel ve toplumsal bir nitelik taşımaktadır. "Düşüncenin doğması ve bildirilmesi bakımından konuşma, kişisel bir etkinliktir. Sözün hemen her zaman başkalarına yöneltilmesi bakımından ise toplumsal bir nitelik taşımaktadır" (Göğüş, 1978: 174). Konuşmanın bu iki özelliği, birbiriyle ilişkilidir. Bireysel boyutu, sosyal boyutunu etkilemekte, sosyal boyutu ise bireysel boyutundan etkilenmektedir.

Ana dili eğitiminin bir yönüyle, sesi kontrol edebilme becerisini kazandırma eğitimi olduğu düşünüldüğünde, ses tözünün doğrudan işlenerek biçimlendirildiği konuşma eğitiminin önemi daha da iyi anlaşılacaktır. Düşüncenin sesle biçimlenmesi sürecinde etkili olan unsurlar aynı zamanda konuşma eğitimini belirleyen unsurlardır. Bu unsurlar, derin yapı yüzey yapı ilişkisi bağlamında ortaya çıkmaktadır.

Zihindeki düşüncenin dil aracılığıyla algılanabilir anlama dönüşmesinde, konuşma sürecinin birinci tözü ses, ikinci tözü görüntüdür. Konuşma eğitiminin bu iki kavram temelinde şekillendirilmesi gerekmektedir. Aşağıdaki şemada, bu süreçte etkili olan unsurlar, derin yapı yüzey yapı ilişkisi bağlamında tespit edilmiştir. Konuşma eğitiminin sınırları çizilirken bu kavramların göz önünde bulundurulması gerekmektedir.

Şema 1: Derin Yapı Yüzey Yapı iliş̧kisinde Konuşma Becerisi

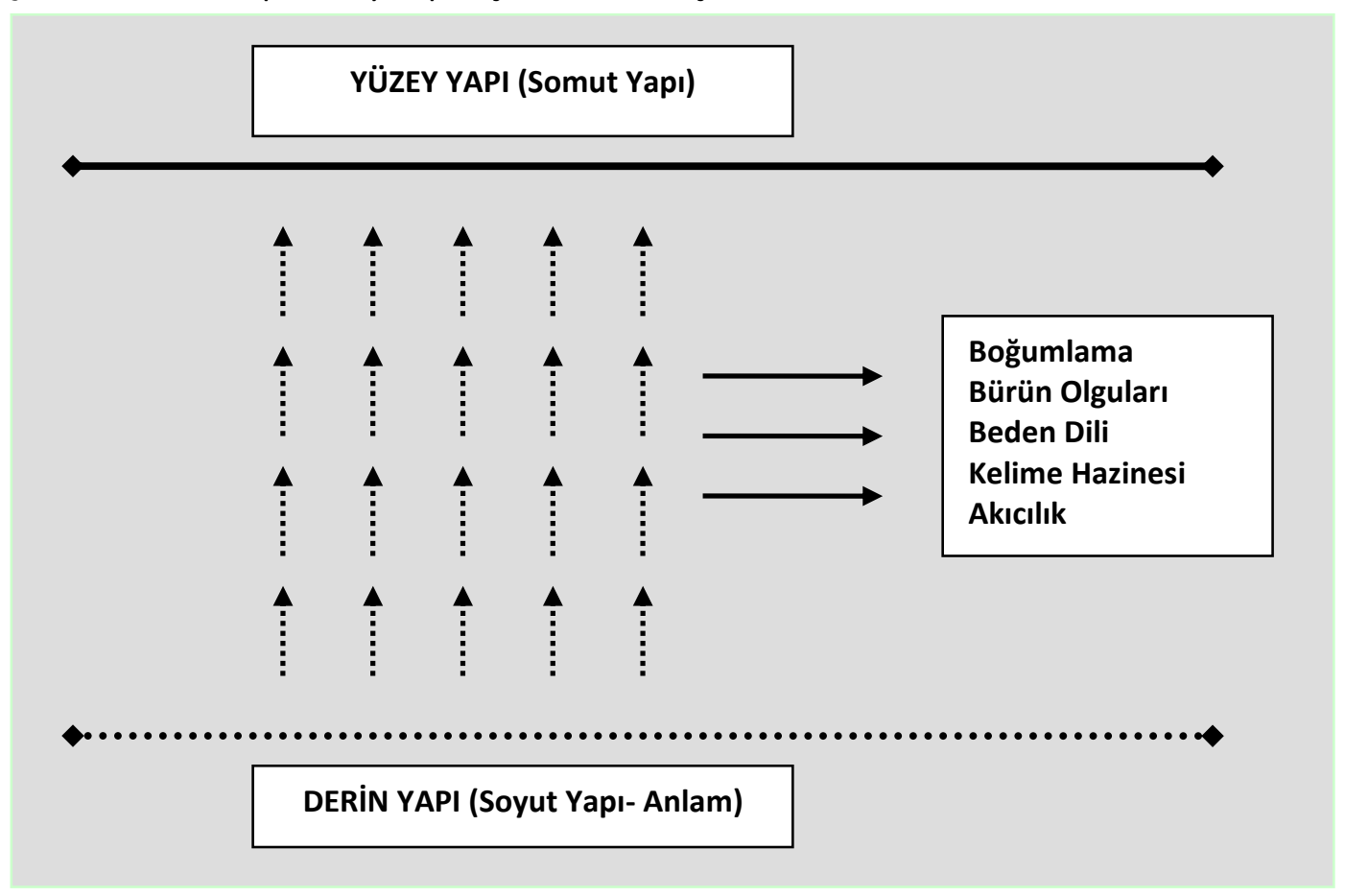


Derin Yapı Yüzey Yapı iliş̧kisi Bağlamında Temel Dil Becerileri Üzerine Bir Analiz Çalışması

Yukarıdaki şema incelendiğinde, konuşmanın oluşum sürecinde boğumlama (söyleyiş), akıcılık, kelime hazinesi, bürün olguları, beden dili gibi hususların etkili olduğu söylenebilir.

Boğumlama, doğrudan doğruya konuşmanın fiziksel yönüyle ilgili bir kavramdır. "Seslerin ve hecelerin herkesin duyabileceği ve anlayabileceği biçimde seslendirilmesi anlamına gelmektedir" (Hengirmen ve Eser, 2005: 136). Bir başka ifadeyle, seslerin konuşma sırasında teşekkül noktalarına uygun olarak çıkarılmasıdır. Boğumlama, derin yapıdaki anlamı, yüzey yapıda ortaya çıkaran ses kodları ile ilgilidir. Boğumlama ne kadar doğru yapılırsa, yüzey yapıda ses kodlarıyla ifade edilen anlam o derece anlaşılır olur. Özellikle ilköğretim birinci sınıf öğrencilerinin okuma yazma öğrenme aşamasında ağız özelliklerinden uzaklaşıp standart Türkçenin tam ses değerlerini kazanmaları son derece önemlidir. Bu dönemde yapılacak ses eğitimi çalışmaları, öğrencilerin telaffuz becerilerini geliştirecektir. Anlamın yüzey yapıda en anlaşılır biçimde temsil edilmesi açısından boğumlama çalışmaları büyük önem taşımaktadır. Düzenli olarak kitap okuyan öğrencilerde boğumlama becerisinin gelişim göstereceği düşünülmektedir.

Akıcılık, konuşmanın hızı ve niteliğiyle ilgilidir. İnsanların algılamakta zorluk çekmeyecekleri bir hızda, yumuşak tonda, vurgu hataları yapmadan ve sözcükleri birbirine karıştırıp yuvarlamadan anlaşııır bir şekilde konuşmaktır. Bu kavram, konuşmanın zihinsel ve fiziksel süreçlerini de yakından ilgilendirmektir. Konuşmanın zihinsel sürecinde, uzun süreli bellekte depolanmış bilgiler, öncelikli olarak kısa süreli belleğe aktarılır ve ardından bu bilgileri dil kodlarına dönüştüren fiziksel süreç başlar. "Bir konuşmanın akıcı olabilmesi için uzun süreli bellekte depolanmış olan bilgilerin, düzenli olması gerekir. Konuşma sırasında, ara bul geriye getir işleminin hızlı bir şekilde gerçekleşmesi, konuşmanın akıcılığını belirleyen önemli hususlardan biridir. Ancak, düzenlenmiş bilgilerle yapılan konuşmalarda akıcılık gözlenir. Yeterince düzenlenmemiş bilgilerle yapılan konuşmalarda, akıcılık bozulur; konuşma yer yer kesintiye uğrar. Bu kesintiler, konuşucunun aktaracağı bilgileri uzun süreli belleğinde arayıp bulamamasından kaynaklanmaktadır" (Onan, 2013: 5). Bilgi işleme modelinde, derin yapıdaki soyut anlamın bulunduğu yer, uzun süreli hafızadır. Uzun süreli hafızadaki anlamın düzenli ya da düzensiz depolanmış olması, konuşmanın akıcılığını doğrudan etkilemektedir. Düzenli bir şekilde depolanmış bilgilerin derin yapıdan yüzey yapıya aktarılması hızı bir şekilde gerçekleştiğinde konuşma akıcı bir nitelik kazanır. Konuşmanın akıcı olması sadece bu hıza bağlı değildir. Telaffuz becerisi, üretici kelime hazinesinin genişliği, bilgi hacmi, nefesin doğru kullanılması gibi hususlar da bu süreçte son derece etkilidir.

Kelime Hazinesi, düşüncenin sözle aktarımında önemli bir araçtır. Kelime hazinesi, "söz kavramının genişliği içinde, dilde kelime ve kelime üstü birimler olan ikileme, deyim, atasözü vb. anlamlı dil birimlerinin oluşturduğu birikimin tümüdür" (Karadağ, 2013: 8). Derin yapıdaki soyut anlamın yüzey yapıya taşınmasında, kişinin üretici kelime hazinesi devreye girer. Üretici kelime 
hazinesi, konuşma ve yazma sürecinde kullanılmaktadır. "Kapsadığı alan, okuma ve dinleme sürecinde kullanılan alıcı kelime hazinesi göre daha sınırlıdır" (Onan, 2013: 245). Bu sınır görecelidir. Kişiden kişiye farklılık göstermektedir. Üretici kelime hazinesi alanı, alıcı kelime hazinesi içerisinde geniş olan kişiler, derin yapıdaki soyut anlamı yüzey yapıya taşımada daha başarılıdırlar. Özellikle, üretici kelime hazinesinin derinlik (bir kelimenin farklı anlam değerlerini bilme) ve genişlik (farklı konularda bilinen kelime miktarı) boyutunda gelişmiş olması, bu başarı düzeyini daha da artırmaktadır. Kelime, konuşma sürecinde anlamın ayrıntı seviyesini belirleyen bir dil birimi olup derin yapıdaki anlamın yüzey yapıya aktarılması sürecindeki anlam kayıplarını en aza indirgeyecek bir potansiyele sahiptir.

Konuşma sürecinde derin yapıdaki soyut anlamın yüzey yapıya taşınmasında etkili olan unsurlardan biri de bürün olgularıdır. Bürün olgusu (parça üstü birim), vurgu, ezgi ve ton kavramlarının genel adıdır. Bürün olguları, dilin bükümlülük özelliğinin bir sonucu olarak ortaya çıkmaktadır. Vurgu, "konuşma sırasında, kelimedeki bir heceyi diğerlerine göre daha yüksek bir ses tonuyla, daha baskılı bir şekilde söyleme anlamına gelmektedir" (Korkmaz, 1992: 164). Konuşma sürecinde vurgunun kelime üzerinde anlam ayıııcı bir işlevi vardır. Derin yapıdaki soyut anlam kümesinde özellikle vurgulanmak istenen anlam birimini taşıyan kelime veya kelime grubu, vurgu yoluyla yüzey yapıda ön plana çıkarılmaktadır.

“Dilin bürünsel özelliklerinden biri sayılan ton, seslemi ilgilendirmektedir ve genel olarak bir seslemdeki sıklık, yükseklik ya da düşüklüğü göstermektedir. Kişinin içinde bulunduğu ruhsal durum ve genel karakteriyle koşutluk gösteren ton, değişik anlamların ortaya çıkmasına neden olabilmektedir" (Ergenç, 1989: 40). Ses tözünün titreşim sayısına bağıı olarak konuşma sırasında alçak veya yüksek ton oluşur. Ses tözündeki yükselip alçalmalar, konuşan kişinin içinde bulunduğu ruh hâli ile ilgilidir. Ses tonuna bağlı olarak konuşan kişinin o anki duygu durumu belirlenebilir. Derin yapıdaki soyut anlamın yüzey yapıya aktarımı sürecinde, kişinin sahip olduğu psikolojik durum, yüzey yapıdaki ses titreşimleriyle anlaşılmaktadır. Bu sebeple, konuşma eğitiminde, dil ötesi birim olarak adlandırılan bürün olgularının kullanımını geliştirmeye yönelik çalışmalara yer verilmesi gerekmektedir.

Beden dili jest, mimik, oturuş şekli, göz teması, kişisel mesafe, giyim tarzı ve renk gibi kavramlardan meydana gelmektedir. Beden dili unsurları, konuşma sırasında derin yapıda oluşan soyut nitelikli anlamı yüzey yapıda görsel olarak ifade eden dil dışı göstergelerdir. Bu göstergeler, yüzey yapıda dille temsil edilen anlamı, görsel olarak desteklemektedir. Yüzey yapının oluşum sürecinde, derin yapıda meydana gelebilecek anlam boşlukları, beden dili kullanımı ile doldurulmaktadır."Yapılan araştırmalar, beden dili unsurlarını etkili olarak kullanan bir konuşmacının ikna gücünün, bu unsurları etkili kullanamayanlara göre daha yüksek olduğunu ortaya koymuştur" (Yalçın, 2002: 138). Bu açıdan bakıldığında, beden dili unsurlarının, anlamın alıcı üzerindeki psikolojik 
etkisini (inandırıcılığını) artırıcı bir işleve sahip olduğu söylenebilir. Ana dili eğitiminde, beden dili unsurlarının konuşma eğitiminin bir parçası olarak değerlendirilmesi gerekmektedir.

Sonuç olarak, derin yapı yüzey yapı ilişkisi bağlamında konuşma süreci incelendiğinde boğumlama, bürün olguları, beden dili, kelime hazinesi ve akıcılık gibi unsurların bu süreçte etkili olduğu görülmektedir. Bu kavramların yazma eğitiminde göz önünde bulundurulması gerekmektedir.

\section{Derin Yapı ve Yüzey Yapı Illişkisi Bağlamında Yazma Eğitimi}

Yazma, anlatıma dayalı bir dil becerisi olup, yazılı dil grubuna girmektedir. Yazma becerisi diğer yandan, ses tözüne dayalı olarak kullanıldığı için yazıı dil becerisi olarak da tanımlanmaktadır. Yazma, doğuştan getirilen bir dil becerisi olmayıp sonradan öğrenilmektedir. En genel tanımıyla, "beyinde yapılandırılmış bilgilerin yazıya dökülmesidir. Yazma sürecine, beyinde yapılandırılmış bilgilerin gözden geçirilmesiyle başlanmaktadır. Yazının amacı, yöntemi, konusu ve sınırları belirlenerek yazılacak bilgiler seçilmektedir. Seçilen bilgiler, çeşitli zihinsel işlemlerden geçirilerek düzenlenmektedir. Bu işlemler; sıralama, sınıflama, ilişki kurma, eleştirme, tahmin etme, analiz sentez yapma, değerlendirme vb. olmaktadır. Bu işlemler sonucunda düzenlenen bilgiler harflere, hecelere, kelimelere ve cümlelere dökülerek aktarılmaktadır” (Güneş, 2007: 160). Konuşma ile karşılaştııılı̆̆ında, yazma sürecinde ön hazırlığın ya da zihinsel hazırlığın daha kapsamlı olduğu görülmektedir.

Yazma sürecinde, beyinde yapılandırılmış bilgilerin gözden geçirilmesi, derin yapı düzleminde gerçekleşmektedir. Derin yapıda ön hazırlık yapıldıktan sonra bilgiler yüzey yapıya taşınmaktadır. Derin yapıdan yüzey yapıya taşınma sürecinde yazma sürecini etkileyen unsurlar aynı zamanda yazma eğitimini de ilgilendirmektedir. Bu unsurlar, aşağıdaki şemada gösterilmektedir. 
Şema 2: Derin Yapı Yüzey Yapı İlişkisinde Yazma Becerisi

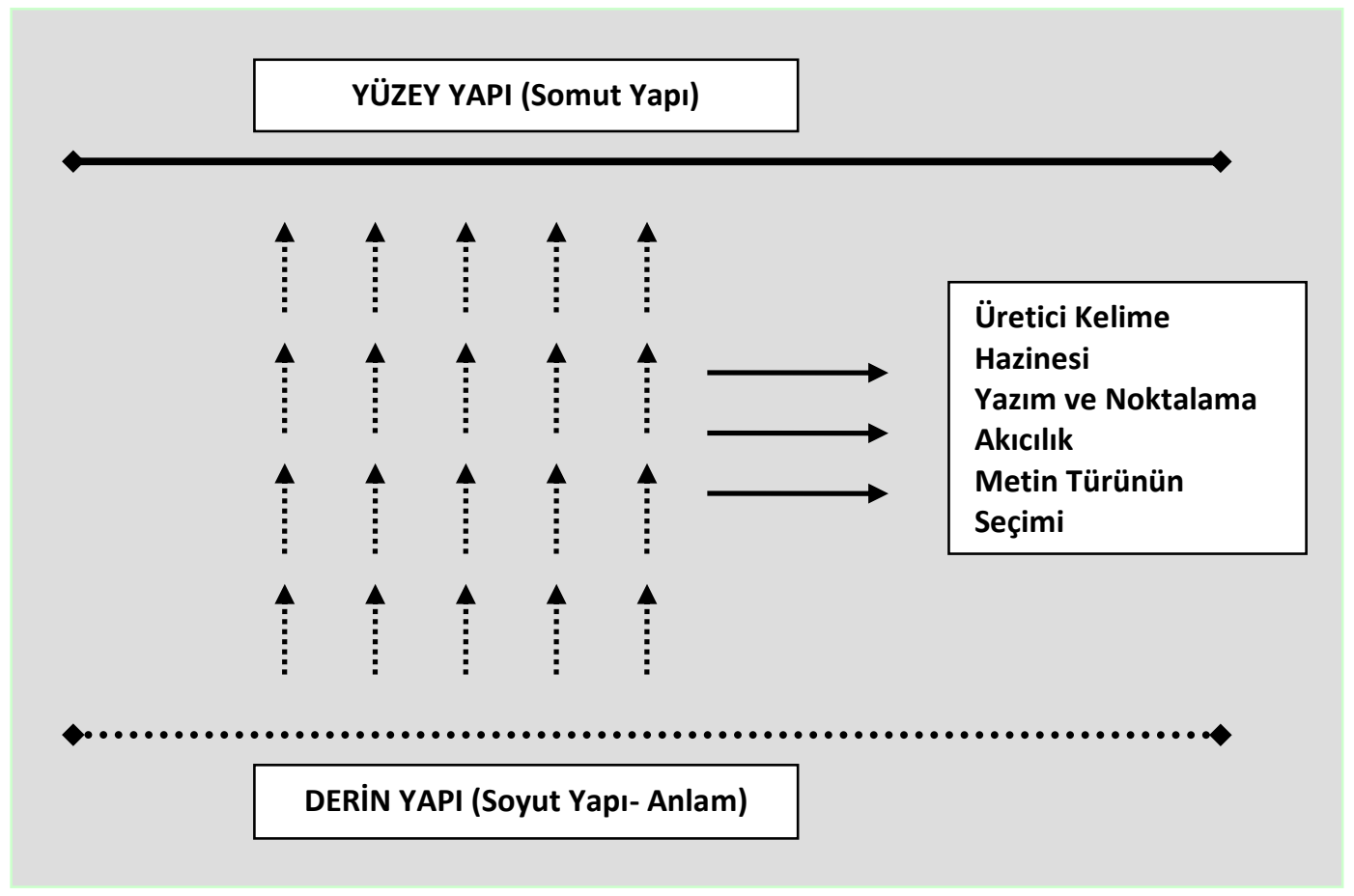

Yukarıdaki şema incelendiğinde, yazmanın oluşum sürecinde; üretici kelime hazinesi, yazım ve noktalama bilgisi, akıcılık, tür bilgisi, bağdaşıklık ve tutarlılık, ön bilgi, yazma tekniği gibi kavramların önemli olduğu görülmektedir. Yazma eğitiminde önemli noktaları belirleyebilmek için bu hususlar üzerinde ayrı ayrı durmak gerekiyor.

Üretici Kelime Hazinesi, konuşma ve yazma sırasında kullanılan kelime hazinesini ifade etmektedir. Yazma sürecinde, derin yapıda oluşan anlamın yüzey yapıya taşınmasında önemli bir işleve sahiptir. Derin yapıda oluşan anlam, dilde doğru karşılıklar bulduğu ölçüde açık ve anlaşılır olacaktır. Üretici kelime hazinesinin niceliği kadar nitelik boyutu da yazma sürecinde anlamın yüzey yapıya aktarılmasında önemlidir. Üretici kelime birikiminin derinlik olarak ifade edilen anlam değerleri yönünden zengin olması, yazma açısından önem taşımaktadır. Soyut anlam olgusunu yazarak somutlaştırmada kelimeler, düşüncenin çözünürlük düzeyini artıran unsurlardır. Anlam, içerik özelliklerine uygun kelimelerle yüzey yapıya taşındığında, anlaşılır olmaktadır. Bu açıdan bakıldığında, ana dili eğitiminde üretici kelime hazinesini derinlik, genişlik ve ağırlık boyutunda geliştirmeye yönelik çalışmalar, dolaylı olarak yazma becerisinin gelişimine de katkı sağlayacaktır.

Yazım ve noktalama, derin yapı yüzey yapı bağlamında yazma sürecini etkileyen iki önemli kavramdır. Yazım (imla), yazma sürecinde tam ses değeri olarak tanımlanan fonemlerle sembolleri birleştirme kurallarıdır. Yazım "bir dilin belirli kurallarla yazıya geçirilmesi olarak da tanımlanmaktadır (TDK; 2009). Yazım kuralları yazma sürecinde özellikle kelimenin yazımıyla ilgili kuralları 
ilgilendirmektedir. Yanlış yazılmış kelimeler, zaman zaman derin yapıdaki soyut anlamın yüzey yapıda yanlış algılanmasına neden olabilir. Yazım yanlışı, anlamı ifade eden ses kodlarının değişmesine neden olmaktadır.

Noktalama işaretleri, "sese ölçü ve değer kazandıran işaretlerdir" (Gökşen, 1967: 105-106). Bir başka açıdan "yazı dilinde prosodic (bürünsel) devinimi kontrol eden trafik işaretleridir. Noktalama işaretleri, konuşma dilindeki bürün olgularını, yazı dilinde okunan metnin daha iyi anlaşııması amacıyla görsel bir mekâna taşıma işlevi üstlenmiştir" (Onan, 2006: 149). Ses unsuru üzerinde etkili olan noktalama işaretleri, konuşmadaki bürün olgularının işlevini yazma sürecinde yerine getirmektedir. Yazma sürecinde anlamın derin yapıdan yüzey yapıya taşınmasında noktalama işaretleri dilin tözü olan sesi kontrol etmektedir. Türk yazı dilinde kullanılan 18 noktalama işaretinden 7'si doğrudan ses tözü üzerinde etkilidir. Bunlar nokta, virgül, noktalı virgül, iki nokta, üç nokta, soru işareti ve ünlem işaretidir. Nokta, bir metni meydana getiren en büyük birim olan cümlenin sınırlarını tayin etmektedir. Bürün olguları açısından değerlendirildiğinde nokta, yazı dilindeki kesinleşmiş durakları göstermektedir. Virgülün cümle anlamı üzerindeki etkisi, bürün olguları ile belirli bir eşgüdüm içerisinde olmasından kaynaklanmaktadır. Virgül, yazı dilinde dilin parçalar üstü birimlerinin cümle içerisindeki seyrine yön vererek bilgi akışını ve odaklanmayı denetler. Virgül, konuşma dilindeki durakların yazı dilindeki karşılığıdır. Anlamı güçlendirme işlevi vardır. İki nokta, yüzey yapıda kendisinden sonra açıklamalar yapılacak cümlelerin sonuna konmaktadır. Üç nokta, tamamlanmamış cümlelerin sonuna konmakta ve eksiltili anlatımlarda kullanılmaktadır. Ünlem, duygunun yazıdaki sembolüdür. Yazma sürecinde cümlenin anlam değerini belirlemede ünlemden yararlanılmaktadır. Ünlemin sembolik işlevi, derin yapıdaki anlamın psikolojik yönünü yüzey yapıya taşırken ortaya çıkmaktadır Onan, (2006: 153-157)’a göre soru işareti, yazma sürecinde cümlenin ezgisini soru ezgisine dönüştürerek soru anlamı oluşturmaktadır. Yazma sürecinde, derin yapıdaki soru anlamı, yüzey yapıda soru işareti ile sağlanmaktadır. Noktalı virgül, derin yapıda oluşan anlamın sürekliliğini sağlamak ve bütünlüğünü korumak için yüzey yapıda oluşan cümleler arasında nokta işareti yerine kullanılmaktadır. Noktalı virgül kullanılarak cümleler arasında söyleyişe dayalı bir süreklilik sağlanmaktadır. "Yazma eylemi bir monolog olduğu için algılanabilir boyutta bir ses olgusundan söz edilemez; bu süreç aynı zamanda bir içten konuşma eylemi olması nedeniyle ses olgusu monologda zaten mevcuttur. Yazma becerilerinin geliştirilmesi sürecinde monologda mevcut olan ses olgusunun anlamla bir eşgüdüm sağlayabilmesi ya da anlamı daha anlaşılır hâle getirmesi için fonolojik unsurlarla denetlenmesi gerekmektedir. Yazma sürecinde bu denetim, noktalama işaretleri ile sağlanmaktadır" (Onan, 2006: 158).

Akıcılık, temel dil becerilerinden okuma, konuşma ve yazma ile ilgili bir kavramdır. Akıcılık, okuyucunun ilgisini azaltacak, dikkatini dağıtacak ayrıntılara yer vermeden noktalama ve imlâ 
kurallarına dikkat ederek yazmak demektir. Akıcı yazma, "duygu ve düşünceleri ifade edebilmek amacıyla gerekli harfleri zihinsel ve bedensel olarak üretebilmektir. Öğrencilere akıcı yazmada kazandırılacak temel beceriler hız ve okunaklılık olmaktadır. Harflerin kolay ve hızlı yazılamaması, öğrencinin düşüncelerini sayfaya aktarmasını güçleştirecektir. Yazmanın yavaş olması, öğrencinin zaman kaybetmesine neden olmaktadır. Bu şekilde yazan öğrenciler, kelime ile çok uğraştıklarından metnin anlamına dikkatlerini verememektedirler" (Güneş, 2007: 107). Yazmada akıcılık, doğrudan yüzey yapıyı oluşturma becerisi / hızı olarak değerlendirilse de, yukarıda belirtildiği gibi anlam üzerinde de etkili olan bir kavramdır. Derin yapıdaki soyut anlamın yüzey yapıya taşınmasında akıcılık, yazma sürecinin niteliğini belirleyici bir unsur olarak karşımıza çıkmaktadır. Soyut nitelikli anlam yapısını sembolleştirme hızı, aktarılan anlamın kalitesini yüzey yapıda dolaylı olarak etkilemektedir. Yazma sürecinde akıcılığı belirleyen unsurlardan biri de üretici kelime hazinesidir. Üretici kelime hazinesi geliş̧̧ş̧ olan öğrenciler, akıcı yazma konusunda daha başarılı olacaktır.

Metin Türünün Seçimi, yazmada derin yapıda oluşan anlamın organizasyonunu ilgilendirmektedir. Metin türünün seçimi, yazma öncesi hazırlık aşaması kapsamında değerlendirilmektedir. Bu aşama, "öğrencilerin seçtikleri konuyu hangi türde, yazacaklarını veya sunacaklarını belirleme çalışmalarını kapsamaktadır" (Güneş, 2007: 181). Derin yapıdaki soyut anlamın yüzey yapıda anlaşılır ve etkileyici bir türle sunumu, metnin anlaşılabilirliğini artıran önemli bir unsurdur. Bu sebeple, derin yapı aşamasında metin türünün belirlenmesi gerekmektedir. Ele alınan konunun niteliği, metin türünün belirlenmesinde önemli bir faktördür.

Ön Bilgi, uzun süreli bellekte önceden depolanmış bilgilerin kısa süreli belleğe taşınmasıyla oluşan bilgidir. Yazılı metnin oluşum sürecinde, derin yapıdaki soyut anlamın bir kısmı ya da tamamı ön bilgilerden oluşmaktadır. Ön bilgi, derin yapıdaki yazma konusuyla ilgili anlamların oluşumunda devreye girmektedir. Seçilen metin türüne göre ön bilgi kullanımı değişmektedir. Konu, bilgilendirici metin türüyle yazılacaksa, ön bilginin yanı sıra, araştırma sürecinde elde edilecek literatür bilgisine de intiyaç vardır. Yazma çalışmalarında uygulanan beyin fırtınası tekniği, derin yapıdaki anlamı ön bilgiler yönünden zenginleştirmektedir.

Tutarlıık, "metin içerisindeki anlamsal ve mantıksal bağlantılar olarak tanımlanmaktadır" (Toklu, 2003: 124-125). Diğer bir ifadeyle, bir metni oluşturan cümleler arasındaki anlamsal uyumdur. Derin yapıdaki anlamların yüzey yapıda bir metin oluşturabilmesi için bu anlamları ifade eden cümleler arasında, mantıksal ve anlamsal bir uyumun olması gerekmektedir.

Yüzey yapıda tutarlılığın oluşabilmesi için biçimsel ilgileri sağlayan bağdaşıklık unsurlarına da dikkat edilmesi gerekmektedir. Günay (2003: 56)'a göre bağdaşıkık, "bir yazının metin olmasını sağlayan metin içi ilişkileri kuran dille ilgili özelliklerin tümünü belirtir. Bu özellikler, metin düzeyinde farklı biçimlerde görülebilir. Yerine göre bir ortak göndergedir; eylem zamanları arasındaki ya da 
adılla yapılan bir art gönderimdir. Dilde bağdaşıklığı oluşturan başka unsurlar da vardır." Bağdaşıklık unsurları, dilin yapısına göre değişmektedir. Derin yapıdaki düşüncelerin yüzey yapıda uygun bağlantılarla bir araya getirilmesi gerekmektedir. Bağdaşıklık ögeleri, derin yapıda aralarında anlam ilgileri olan düşünceleri yüzey yapıda birbirine bağlayarak metnin oluşum sürecine katkıda bulunmaktadır. Bağdaşıklık unsurları kullanılmadan yüzey yapıda anlamlı bir metin oluşturulamaz. Bu noktada yazarın dil kurallarına ait bilgileri devreye girmektedir.

Sonuç olarak, derin yapı yüzey yapı ilişkisi bağlamında yazma süreci incelendiğinde üretici kelime hazinesi, yazım ve noktalama, akıcılık, metin türü, bağdaşıkık, tutarlıık ve ön bilgi gibi unsurların bu süreçte etkili olduğu görülmektedir. Bu kavramların yazma eğitiminde göz önünde bulundurulması gerekmektedir.

\section{Derin Yapı ve Yüzey Yapı iliş̧kisi Bağlamında Okuma Eğitimi}

Okuma, anlamaya dayalı bir dil becerisi olup, yazılı dil becerisi grubuna girmektedir. Diğer dil becerilerinde olduğu gibi okuma becerisinde de dilin ses tözü kullanılmaktadır. Okumada ses tözü, semboller (harfler) vasıtasıyla biçime dönüşmektedir. Yazmada olduğu gibi, doğuştan getirilen bir dil becerisi olmayıp sonradan öğrenilmektedir. Okuma, Akyol (2005: 1)’a göre, “ön bilgilerin kullanıldığı, yazar ve okuyucu arasındaki etkili iletişime dayalı, uygun bir yöntem ve amaç doğrultusunda düzenli bir ortamda gerçekleştirilen anlam kurma süreci"dir. Diğer dil becerilerinde olduğu gibi fiziksel ve zihinsel süreçleri olan bir beceridir. Okumanın zihinsel boyutunu önemli ölçüde "anlam kurma" aşaması oluşturmaktadır.

Okumada anlam kurma süreci yüzey yapıdan derin yapıya doğru gerçekleşmektedir. Fiziksel süreçte algılanan harfler sese dönüştürülmekte, seslerin oluşturduğu işitim imgeleri aracılığıyla anlama yani derin yapıya ulaşılmaktadır. Okumada, yüzey yapıdan derin yapıya taşınma sürecini etkileyen unsurlar aynı zamanda okuma eğitimini de ilgilendirmektedir. Bu unsurlar, aşağıdaki şemada gösterilmiştir. 
Şema 2: Derin Yapı Yüzey Yapı Illişkisinde Okuma Becerisi

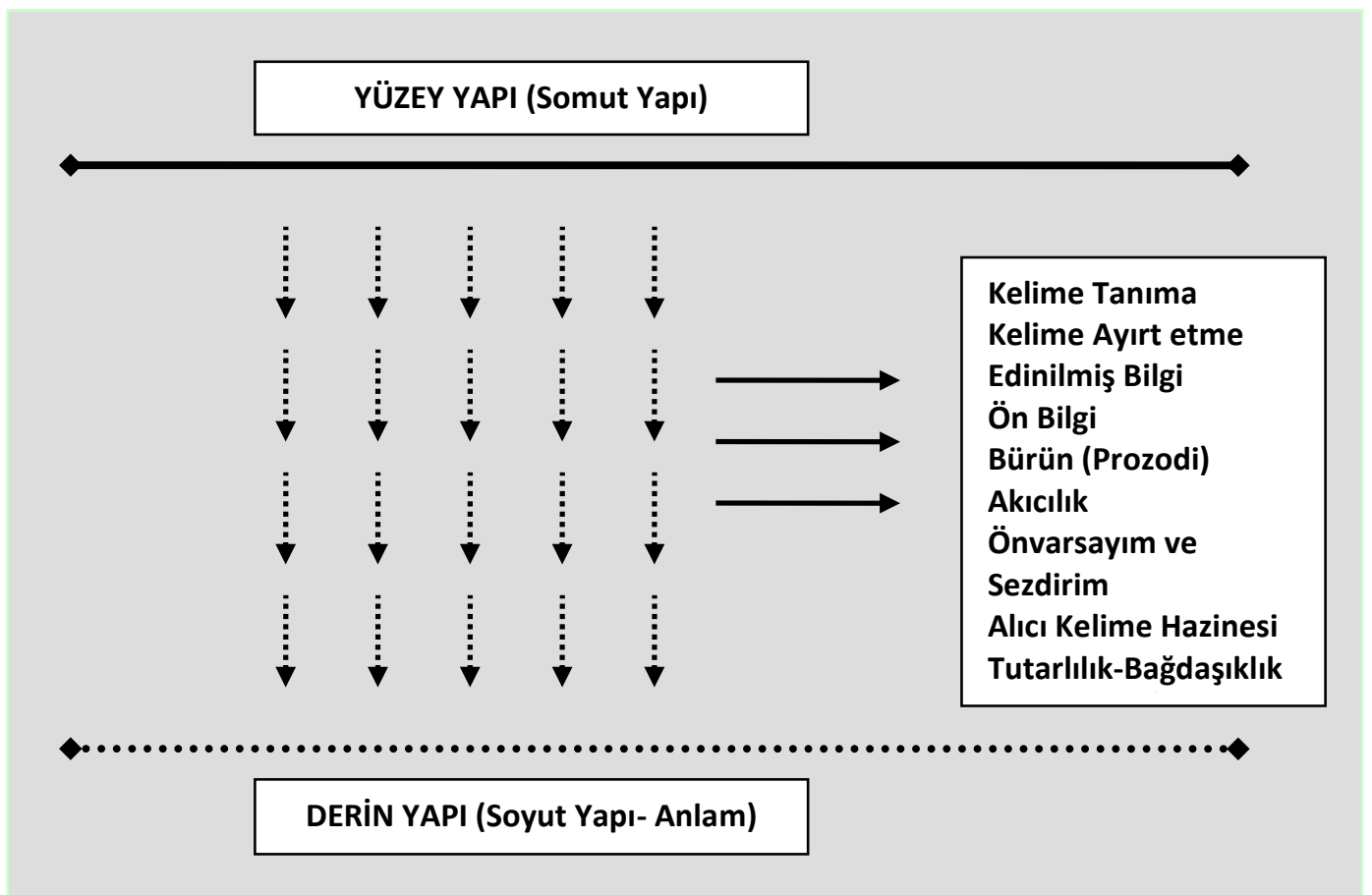

Yukarıdaki şema incelendiğinde, okumanın oluşum sürecinde; kelime tanıma, kelime ayırt etme, edinilmiş bilgi, ön bilgi, bürün olguları, akıcılık, önvarsayım, sezdirim, alıcı kelime hazinesi, tutarlıık, bağdaşıklık ve noktalama işaretleri gibi unsurların etkili olduğu görülmektedir. Okuma eğitiminin önemli noktalarını belirleyebilmek için bu hususlar üzerinde ayrı ayrı durmak gerekiyor.

Kelime tanıma "verilen kelime veya kelimeleri doğru bir şekilde seslendirmektir" (Akyol, 2005: 152). Kelime tanıma, bir kelimeyi meydana getiren sesleri standart dildeki fonem (ses) değerlerine göre okumayı ifade eder. Okuma süreci, metnin yapısındaki kodların çözülmesiyle başlar, okurun cümledeki anlam öbeklerine ulaşabilmesi için öncelikle bu anlam öbeklerini oluşturan işitim kümelerini (kelimeleri), yüzey yapıda oluşturması gerekir. Bunun için, dildeki fonemlerle onların karşıı̆ı̆ı olan sembolleri hızlı ve akıcı bir şekilde eşleştirebilmesi gerekmektedir. Kelime tanıma becerisinin kazanılması, ilkokul birinci sınıf öğrencileri için büyük önem taşımaktadır.

Kelime ayırt etme, "kelimeyi hem doğru seslendirme hem de anlamını bilmektir. Kelime ayırt etme, kelime tanımayı da kapsamaktadır. Kelime tanımayı anlamı taşıyan araç, anlamı ise aracın taşıdığı mesaj olarak düşünebiliriz" (Akyol, 2005: 152). Kelime ayırt etme, kelimeyi ses ve özellikle anlam yönüyle diğer kelimelerden ayırabilme becerisidir. Bu kavram, okuma ve yazma açısından önem taşımaktadır. Okuma anlama sürecinde, yüzey yapıdaki kod çözme işleminin tamamlanmasıyla doğal olarak kelime ayırt etme işlemi de gerçekleşmelidir. Bu beceri doğrudan doğruya öğrencilerin sözcük düzeyinde anlam bilgileriyle ilgilidir. Öğrencilerin, kelimelerin anlam değerlerine ne oranda hâkim olduklarını ilgilendirmektedir. Okuma sürecinde metnin yüzey yapısındaki kelimeler farklı 
anlam değerlerine sahiptir. Bir kelimenin anlam yönünden olası değerlerini ayırt edemeyen öğrenciler, derin yapıya ulaşamaz.

Herhangi bir konuyla ilgili olarak, kişinin uzun süreli belleğinde depoladığı bilgi, edinilmiş bilgi olarak tanımlanmaktadır. Bilişsel psikolojide, edinilmiş bilginin karşılı̆̆ı şemadır. Edinilmiş bilgiler, öğrencinin okuma sürecine getirdiği zihin yapısını belirler; sınıflandırılmış ya da sınıflandırılmamış olabilir. Sınıflandırılmış olması, okuma sürecinde ön bilgi oluşumunu doğrudan ilgilendirmektedir. Düzenlenmiş şemalar, okuma anlama sürecinde kısa süreli bellekte ön bilgi olarak devreye girer ve derin yapıya ulaşma sürecine katkıda bulunur. Okurun derin yapıyla etkileşime girmesi, ön bilgiler vasıtasıyla gerçekleşmektedir.

Ön bilgiler, uzun süreli bellekteki edinilmiş bilgilerin kısa süreli belleğe çağrılmasıyla oluşmaktadır. Ön bilgiler, okuma sürecinde öğrencinin zihin yapısını belirler. Okuduğu metin hakkında ön bilgileri yeterli olan öğrenciler, metnin yüzey yapısından derin yapısına daha hızlı bir şekilde ulaşabilirler. Bunun temel sebebi, ön bilgilerin okuma sırasında metnin derin yapısındaki yeni bilgilerle kurulmaya çalışılan dengeleme sürecini hızlandırmasıdır. Metnin derin yapısındaki yeni bilgilere uyum sağlamaya çalışan öğrenci bu süreçte uzun süreli bellekten kısa süreli belleğe taşıdığı ön bilgilerini kullanır.

Okuma sürecinde, yüzey yapıdan derin yapıdaki soyut anlama ulaşmada etkili olan unsurlardan biri de bürün olgularıdır. Daha önce, konuşma bölümünde ifade edildiği gibi bürün olgusu kavşak, durak, vurgu, ezgi, ton ve süre kavramlarının genel adıdır. Bürün olgusu, dildeki ses esnekliğinin bir sonucu olarak ortaya çıkmaktadır. Okuma anlama sürecinde, yüzey yapıdaki kelime ve cümlelerin bürünsel özellikleri, derin yapıya ulaşmada bir araç olarak kullanılabilir. Özellikle edebî metinlerde bürün olgularının doğru kullanılmasıyla derin yapı oluşturma süreci birbiriyle bağlantıııdır. Bürün olgularının okumadaki temel işlevi, okumanın nasıl olması gerektiği noktasındadır. Bu durumda, metnin yüzey yapısında, kullanılan noktalama işaretleri, okuma sırasında ses üzerinde yönlendirici bir işleve sahiptir. Noktalama işaretlerinin okuma sürecindeki etkisi, anlama oluşturma aşamasında devreye girmektedir. Okuma sırasında, ses ve anlam arasındaki ilişkinin yani fonoseminin okur tarafından sağlanması gerekmektedir. Fonosemi "Sesin anlam telkin etmesi demektir" (Dilâçar, 1968: 8). Özellikle şiir ve tiyatro türündeki edebî eserlerde, ses ve anlam arasındaki ilişkinin derin yapı oluşturma sürecine önemli bir katkısı vardır. Özetle kavşak, vurgu, ezgi, ton, durak, süre gibi unsurlar okuma sürecinde yüzey yapıda işlevsel olup derin yapıyı da dolaylı olarak etkilemektedir.

Okuma açısından akıcılık "metindeki kelimeleri tanımak, metni belirli bir çabuklukta ve düzgün bir ifadeyle okumak demektir. Akıcı okumada, vurgu ve tonlamalara dikkat edilmeli, gereksiz tekrarlama, duraklama, atlama vb. yapılmamalıdır. Akıcı okuma kelime kelimenin hızı tanınması, seslendirilmesi ve anlamının bulunması işlemleri sonucunda gerçekleşmektedir. Akıcı okumada 
öğrencilerin nefeslerini kontrol etme, uygun yerlerde durma ve metnin anlamını yakalama gibi becerileri de gerekmektedir" (Güneş, 2007: 92). Akıcılık, okuma sürecinde yüzey yapıdaki kodların çözümüyle ilgili olup derin yapıyı da yakından ilgilendiren bir kavramdır. Derin yapıyı oluşturan anlam öbekleri açısından anlamsal bütünlüğün sağlanabilmesi ve bağlamın oluşabilmesi için okuma sırasında, metnin yüzey yapısındaki kodların belirli bir hızda çözülmesi gerekmektedir. Okuma hızı normalden düşük olduğunda, derin yapıyı oluşturan anlam öbekleri arasında bir bütünlük sağlanamaz. Bu durum okuma sürecini olumsuz yönde etkileyecektir.

Okuma sürecinde, derin yapı yüzey yapı bağlamında üzerinde durulması gereken önemli kavramlardan biri de önvarsayımdır. Okuma sürecindeki işlevlerine geçmeden önce, kavramla ilgili tanımlara göz atmak gerekir. Önvarsayım " bir sözcede dinleyiciye ulaştırılmak istenen bildirinin dışında kalan, tartışma götürmeyecek şekilde sunulan bilgidir" (Vardar, 1998: 162). Önvarsayımda, üzerinde uzlaşıma varılmış bilgi olma özelliği vardır. Kıran (2001:222)'a göre önvarsayım “tümcenin yüzey yapısında görünmeyen anlamın parçaları arasındadır." Günay (2003:70)'a göre önvarsayım "kullanım bağlamından çıkartılabilecek bazı örtük bilgileri belirtir. Bu bilgiler çerçevesinde, önvarsayım kavramının temel özellikleri şu şekilde belirlenebilir. "Önvarsayım bilgisi, iletilmek istenen asıl bildirinin dışında kalmaktadır. Uzlaşımsal niteliklidir. Doğruluğu tartışılmaz. Tümcenin yüzey yapısında doğrudan görülmez. Edimsöz niteliği taşır. Dilsel ipuçları kullanılarak ulaşılır (Onan ve Tiryaki, 2012: 236). Okuma sürecinde, metnin yüzey yapısında verilen ana bilginin dışındaki diğer bilgilere ya da derin yapılara ulaşmada dilsel ipuçlarının kullanımı önemlidir. Yüzey yapıda yer alan bazı kelimeler, okuma sürecinde derin yapılara ulaşmak için birer araç işlevi görmektedir.

Okuma sürecinde önemli olduğu düşünülen ve önvarsayımla da ilgili olan kavramlardan biri de sezdirimlerdir. "Sezdirim, bir bağlam ya da sözceleme durumunda verilen bilgilerden çıkarım yoluyla ulaşılabilecek bir bilgiyi belirtir. Tümcenin var olan yapısı içinde, anlamsal ya da mantıksal akıl yürütme ile kazanılacak ek bilgileri içerir. Anlatı açısından her şeyi yüzey yapıda belirtmemek için yazar çoğunlukla bazı şeyleri sezdirir. Sezdirim, vericinin metinde açık olarak belirtmediği ama dolaylı olarak çıkarılmasını istediği bilgilerdir" (Günay, 2003: 66-67). Bu açıklamalar çerçevesinde, sezdirimin temel özellikleri şu şekilde tespit edilebilir; "Bağlam ya da sözceleme durumundan çıkarılır. Sezdirimlerde mantıksal akıl yürütme vardır. Alanın bilgi alt yapısı, sezdirimde ön plana çıkar. Anlamsal ipuçları kullanılarak çıkarsama yapılıı" (Onan ve Tiryaki, 2012: 236). Okuma sürecinde sezdirim bilgisine ulaşma doğrudan derin yapı üzerinde yapılan bir işlemdir. Okuyucunun derin yapı üzerinde sezdirim işlemi yapabilmesi için metinde ele alınan konuyla ilgili bir ön bilgiye sahip olması gerekir. Sezdirim bilgisi, okuyucu açısından bütünü (bağlamı) algılama becerisini de gerektirmektedir. Okuyucu, derin yapıdaki ipuçlarına ulaşırken yüzey yapıda verilmiş olan anlamsal ipuçlarını kullanır. Sezdirim, öğrencilerin akıl yürütme ve çıkarım yapma becerilerini geliştirir. Sezdirim yoluyla, 
öğrencinin sahip olduğu bilgi alt yapısı (ön bilgiler) harekete geçer. Öğrenciler sezdirim bilgisine ulaşırken, sahip oldukları ön bilgileri metnin derin yapısıyla bir araya getirip etkileşim kurarlar. Bu etkileşim sonucunda metnin derin yapısını genişleten sezdirim bilgisine ulaşırlar.

Alıcı kelime hazinesi, okuma anlama sürecinde devreye girmektedir. Dil eğitimi açısından kelime hazinesinin en geniş bölümünü oluşturmaktadır. Alıcı kelime hazinesi derinlik, genişlik ve ağırlık yönünden gelişmiş öğrenciler, okuma anlama sürecinde yüzey yapının geri planındaki derin yapıları daha doğru ve hızlı bir şekilde çözümleyeceklerdir. Okuma açısından alııı kelime hazinesinin en önemli boyutunu derinlik oluşturmaktadır. Derinlik, kelimenin farklı anlam değerlerini ifade eden bir kavramdır. Bir kelimenin derin yapıdaki anlam değerini yüzey yapı dizgesindeki ilişkiler ve bağıntılar oluşturmaktadır. Kelimelerin derin yapıdaki olası anlam değerlerini tespit edebilmek için yüzey yapıdaki ilişkiler ağının okuma sırasında fark edilmesi gerekmektedir.

Noktalama işaretleri, okuma sırasında söz dizimi yapısı üzerinde sesi yönlendiren ve anlam üzerinde etkili olan birimlerdir. Bu açıdan bakıldığında, bir noktalama işareti olarak virgülün yüzey yapı dizgesindeki durak noktalarını belirleyerek anlam üzerinde belirleyici bir işlevi olduğu söylenebilir. "Bir tümce içindeki anlam birlikleri, verilecek kısa duraklamalarla ayrılır. Konuşucunun iletmek istediği duygu ve düşüncelerin en etkili ve anlaşılır biçimde alıcı tarafından algılanabilmesine yardımcı olan duraklar, dilimizde gereği gibi kullanılmadığında yanlış anlamalara neden olacak ölçüde önemli ve anlam ayırıcı özellikler taşımaktadır" (Ergenç, 1989: 38-39). Virgül, okuma sırasında metnin yüzey yapısındaki durak noktalarını işaret ederek okuyucuyu yönlendirmektedir. Aynı şekilde nokta ve soru işareti de okuma sırasında yüzey yapı dizgesinde ses üzerinden anlamı etkileyen noktalama işaretleridir. Nokta, metnin yüzey yapısındaki anlamın sınırını biten ezgi vasıtasıyla belirler. Soru işareti, metnin yüzey yapısında, derin yapıyı etkileyen soru ezgisi oluşturmaktadır.

Bağdaşıklık, okuma metninin yüzey yapısını oluşturan söz dizimi yapıları arasındaki gramatik bağlantılardır. Söz dizimi yapısı içindeki ilişkileri de ilgilendirmektedir. Gönderim ve değiştirim ögelerinden meydana gelmektedir. Okuma anlama sürecindeki işlevi, metnin derin yapısındaki ilişkileri belirleyecek yüzey yapı bağlantılarını oluşturmasıdır.

Metnin derin yapısının okuyucunun zihninde bir bütün teşkil edebilmesi için metni meydana getiren cümlelerin kendi arasında anlamsal yönden tutarlılık göstermesi gerekir. Bu açıdan bakıldığında tutarlılık, okuma - anlama sürecini doğrudan ilgilendirmektedir. Tutarlılık özelliği göstermeyen bir metnin karşısında okuyucu, metnin derin yapısını oluşturan unsurlar arasında bir bütün oluşturamaz. Bu durum, okuma - anlama sürecini olumsuz yönde etkileyecektir.

Sonuç olarak, derin yapı yüzey yapı ilişkisi bağlamında okuma - anlama süreci incelendiğinde kelime tanıma, kelime ayırt etme, edinilmiş bilgi, ön bilgi, bürün (prozodi), akıclık, önvarsayım, sezdirim, alııı kelime hazinesi, tutarlıık, bağdaşıklık ve noktalama işaretleri gibi hususların bu süreçte 
etkili olduğu görülmektedir. Bu kavramların okuma eğitiminde göz önünde bulundurulması gerekmektedir.

\section{Derin Yapı ve Yüzey Yapı İlişkisi Bağlamında Dinleme Eğitimi}

Dinleme, anlamaya dayalı bir dil becerisi olup, sözlü dil becerisi grubuna girmektedir. Yazma, okuma ve konuşma becerilerinde olduğu gibi dinleme becerisinde de dilin ses tözü kullanılmaktadır. Dinlemede ses tözü doğrudan kullanılmaktadır. Bu sebeple dinleme, sözlü dil becerisi olarak da tanımlanmaktadır. Dinleme, doğuştan getirilen ve sosyal çevrede gelişen bir beceridir. Dil gelişiminde ilk edinilen dil becerisi olma özelliğine sahiptir. Dinleme "dinleyicinin önce söylenenlerle sonra söylenenler arasında bağlantı kurma ve iletişim içindeki yerini anlama yeteneğidir" (Temur, 2001: 61). Diğer bir tanıma göre dinleme "sözlü iletişim sürecinde, konuşan tarafından ses birimleri vasıtasıyla gönderilen mesajların alıı kişinin zihninde deşifre edilip bilgiye dönüştürüldüğü zihinsel bir süreçtir" (Onan, 2013: 129). Dinlemede yüksek düzeyde ses kontrolü ve derin yapıya dönüştürme işlemiyle birlikte tepki eylemi de gerçekleşmektedir. "Bazı eğitimci ve araştırmacılar, dinlemenin tanımında tepki unsurunun mutlaka bulunması gerektiğini ifade etmektedirler. Bu, vericinin gönderdiği mesajın alıcı tarafından anlamlandırımasından sonra, alıcıdan vericiye olumlu veya olumsuz duruma uygun tepkilerin verilmesidir" (Özbay, 2009: 48). Dinlemede anlam kurma süreci yüzey yapıdan derin yapıya doğru gerçekleşmektedir. Algılanan sesler yüzey yapıda işitim imgeleri oluşturmakta, işitim imgeleri işitim öbeklerine işitim öbekleri ise söz dizimi nitelikli işitim dizgelerine dönüştürülmektedir. Yüzey yapıdaki fiziksel işlemler tamamlandıktan sonra derin yapı süreci başlamaktadır. Dinlemede yüzey yapıdan derin yapıya taşınma sürecinde etkili olan unsurlar aynı zamanda dinleme eğitimini de ilgilendirmektedir. Bu unsurlar, aşağıdaki şemada gösterilmiştir. 
Şema 2: Derin Yapı Yüzey Yapı Iliş̧kisinde Dinleme Becerisi

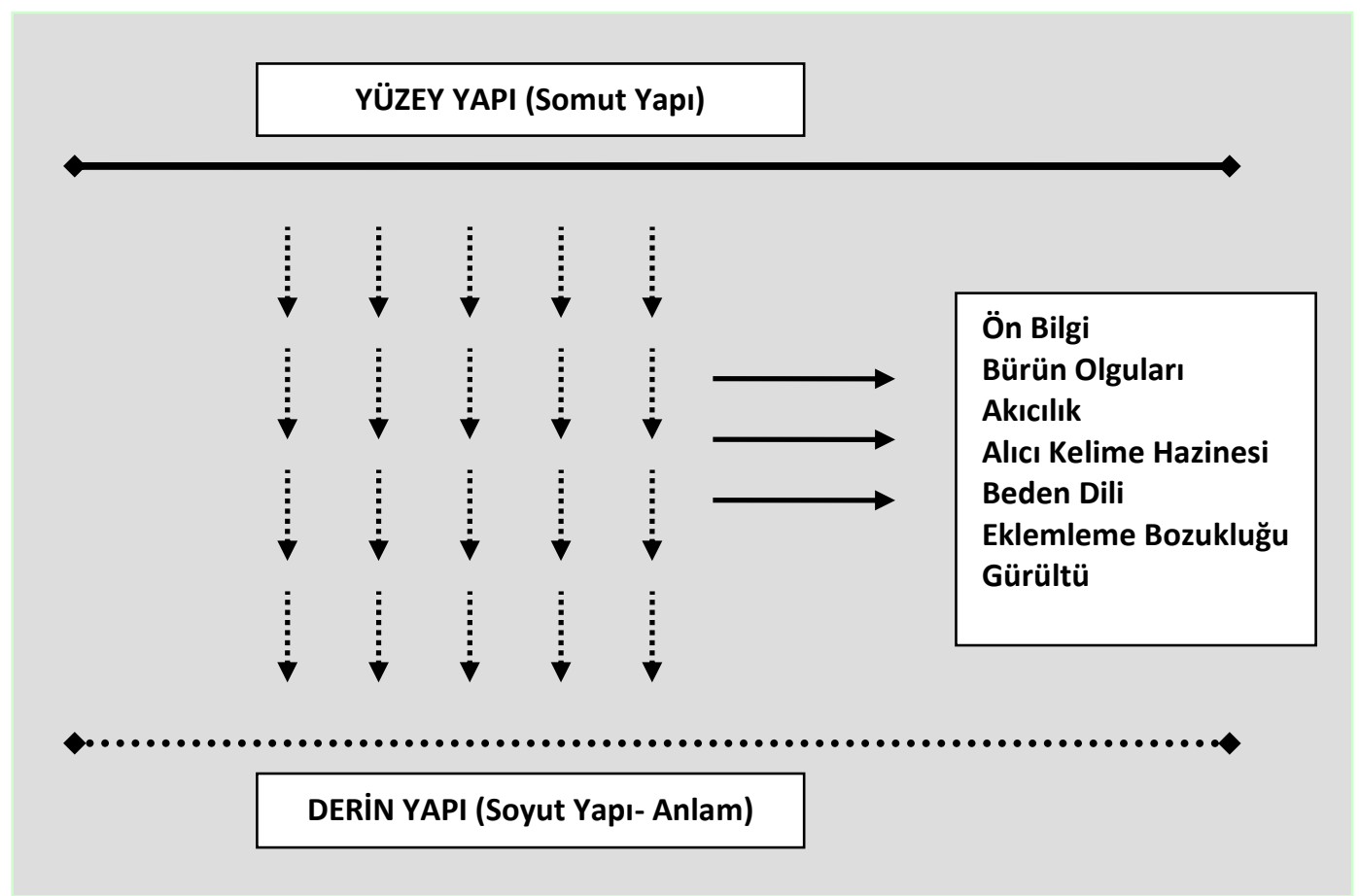

Yukarıdaki şema incelendiğinde, dinlemenin oluşum sürecinde; ön bilgi, bürün olguları, akıcılık, alıcı kelime hazinesi, beden dili, eklemleme ve gürültü gibi unsurların etkili olduğu görülmektedir. Dinleme eğitiminin önemli noktalarını belirleyebilmek için bu hususlar üzerinde ayrı ayrı durmak gerekiyor.

Ön bilgi, uzun süreli bellekteki edinilmiş bilgilerin kısa süreli belleğe çağrılmasıyla oluşmaktadır. Ön bilgi doğrudan da oluşturulabilir. Dinleme sürecinde, yüzey yapıdaki işitsel kod açma işleminden sonra derin yapıdaki anlama ulaşma ve yorum yapma süreçlerinin hızlı bir şekilde gerçekleşebilmesi için dinleyicinin, dinlediği konuyla ilgili ön bilgilere sahip olması gerekmektedir. Dinleme sürecinde ön bilgi, konuşmacı tarafından oluşturulabileceği gibi bizzat dinleyicinin konu hakkında yapacağı araştırmalarla da elde edilebilir.

Dinleme sürecinde, yüzey yapıdan derin yapıdaki soyut anlama ulaşmada etkili olan unsurlardan biri de bürün olgularıdır. Daha önce, konuşma ve okuma bölümlerinde de ifade edildiği gibi bürün olgusu kavşak, durak, vurgu, ezgi, ton ve süre kavramlarının genel adıdır. Bürün olgusu, dildeki ses esnekliğinin sonucu olarak ortaya çıkan bir bükümlülük durumdur. Dinleme sırasında dinleyiciyi anlama yönlendirme işlevine sahiptir. Özellikle vurgu, ezgi, ton ve durak gibi prozodik unsurlar, dinleyiciyi derin yapıya yönlendirmede işlevseldir.

Akıcılık, dinleme sürecini dolaylı olarak ilgilendirmektedir. Akıcılık "söylenen, yazılan sözlerin dile takılmadan kolayca ve ahenkli bir biçimde okunup anlaşılabilmesi hâlidir" (Karataş, 2004: 26). 
Dinlemedeki akıcılık, konuşmacıya bağlıdır. Konuşmanın akıcı olması, dinleyicinin yüzey yapıdan derin yapıya geçiş sürecini hızlandırmaktadır. Akıcı bir konuşma karşısında dinleyici, bilgi içeren derin yapı kodlarını daha kısa sürede açacaktır. Dinleyici yönünden akıcılık, zihinsel dikkatin sürekliliği açısından da önem taşımaktadır. Zihinsel dikkatin sürekli olması, dinleyicinin yüzey ve derin yapılar üzerindeki işlem süresini uzatmaktadır.

Dinleme sürecini etkileyen bir diğer önemli husus, alıcı kelime hazinesidir. Daha önce de ifade edildiği gibi, alıcı kelime hazinesi okuma ve dinleme sürecinde devreye girmektedir. Dinleyicinin sahip olduğu alıcı kelime hazinesinin nicelik ve nitelik düzeyi konuşma metnindeki yüzey yapı kodlarının çözüm sürecini hızlandırdığı gibi metnin derin yapı potansiyelinden en üst düzeyde yararlanmayı da sağlamaktadır. Özellikle, alıcı kelime hazinesi derinlik boyutunda gelişmiş kişiler, metnin derin yapısını ayrıntılı bir şekilde çözümleyebilmektedirler.

Konuşma sürecine eşlik eden beden dilinin dinleyicinin derin yapıya ulaşma sürecinde belirleyici etkileri vardır. Dinleme sürecinde, ne söylendiği kadar nasıl söylendiği de önemlidir. Jest, mimik ve postürden (duruştan) oluşan beden dili unsurları, mesajın nasıl ifade edildiğini ilgilendirmektedir. Bu açıdan bakıldığında, dinleyicinin dinleme sürecinde çözmek zorunda olduğu iki tür yüzey yapı kodu olduğu söylenebilir. Bunlardan biri dile ait yüzey yapı kodları, diğeri ise beden diline ait kodlardır. Dil dışı görsel gösterge olma özelliği gösteren beden dili unsurları, görsel nitelikli oldukları için dinleyiciye derin yapıyı çok boyutlu değerlendirme imkânı vermektedir.

Eklemleme (Artikülasyon), "nefesin gırtlaktan çıktıktan sonra yutak, ağız ve burundan oluşan üçüncü küme organlarında (dil, diş, damak, dudakta) konuşma dilimizin geleneksel seslerine dönüşüp biçimlenmesidir. Birey, ana dilinin bağımsız ya da bileşik seslerini doğru ve anlaşıı biçimde çıkaramıyor, birbirine gereği gibi ulayamıyor ya da bu seslerin çıkarılması ve ulanmasında onun yaşından beklenenden çok fazla sapma görülüyorsa onda eklemleme (artikülasyon) bozukluğu var demektir" (Özgür, 2006: 17). Eklemleme bozukluğu dinleme sürecini dolaylı olarak ilgilendirmektedir. Konuşmacının yaptığı eklemleme hataları dinleme sürecinde, dinleyicinin yüzey yapı kodlarını çözmesinde kendinden kaynaklanmayan işitsel bir engel oluşturacaktır. Yüzey yapı kodlarını çözemeyen dinleyici, konuşma metninin derin yapısına ulaşamaz.

Dinleme sürecini etkileyen önemli faktörlerden biri de gürültüdür. "Kaynaktan çıkan mesajın alıcı tarafından tam ve doğru olarak alınmasını etkileyen her şey gürültü olarak tanımlanmaktadır. Gürültü göndericiden, alıcıdan ve kanaldan kaynaklanabilir. Fiziksel gürültü, nöro-fizyolojik gürültü ve psikolojik gürültü olmak üzere üç gruba ayrılmaktadır. Fiziksel engeller, fiziksel gürültü kaynağıdır. Duyu organlarındaki yetersizlikler, nöro-fizyolojik gürültüye sebep olur. Alıcının iç dünyasından kaynaklanan engeller, dinleme sürecinde psikolojik gürültü kaynağı olarak tanımlanmaktadır" (Kaya, 2010: 11). Gürültü, dinleme sürecini olumsuz yönde etkileyen faktörlerden biridir. Gürültünün 
dinleme sürecinde oluşturduğu engel, konuşmacıdan gelen kodlara ulaşma noktasında ortaya çıkmaktadır. Gürültü, dinleyicinin yüzey yapı kodlarına ulaşmasını engellemektedir. Bu durumda dinleyici yüzey yapı kodlarını çözümleyemez ve derin yapıdaki mesaja ulaşamaz. Bazı durumlarda gürültü, yüzey yapıdaki kodların yanlış algılanmasına da neden olabilmektedir. Bu durum, dinleyicinin doğru olmayan derin yapılar üzerinde zihinsel işlem yapmasına neden olmaktadır.

\section{Sonuç}

Illk kez 17. yüzyılda Port Royal Okulu tarafından ortaya konan ve daha sonra 1965 yılında Üretici - Dönüşümsel Dilbilgisinin ikinci aşaması olan Standart Kuram çerçevesinde Noam Chomsky tarafından tekrar gündeme getirilen derin yapı yüzey yapı kavramları çerçevesinde, temel dil becerilerinin analiz edildiği bu çalışmada şu bulgulara ulaşılmıştır:

Konuşma becerisinin oluşumunda boğumlama, bürün olguları, beden dili, üretici kelime hazinesi, akıcılık kavramlarının yüzey yapı ve derin yapıda gerçekleşen işlemlerle ilgili olduğu belirlenmiştir.

Konuşma becerisinde boğumlama yüzey yapı ile ilgili olup, diğer unsurlar derin yapıyı ilgilendirmektedir. Konuşma sürecinde, derin yapıdan yüzey yapıya ilerleyen zihinsel bir süreç söz konusudur.

Yazma becerisinin oluşumunda üretici kelime hazinesi, yazım ve noktalama, akıcılık, metin türünün seçimi, bağdaşıklık, tutarlıık ve ön bilgi kavramları öne çıkmaktadır. Yazma sürecinde, derin yapıdan yüzey yapıya ilerleyen zihinsel bir süreç vardır.

Okuma becerisinin oluşumunda kelime tanıma, kelime ayırt etme, ön bilgi, edinilmiş bilgi, bürün olguları, akıcılık, önvarsayım, sezdirim, alıcı kelime hazinesi, tutarlılık, bağdaşıklık, noktalama işaretleri gibi kavramlar öne çıkmaktadır. Okuma sürecinde, yüzey yapıdan derin yapıya doğru ilerleyen zihinsel bir süreç söz konusudur.

Dinleme becerisinin oluşumunda ön bilgi, bürün olguları, akıcılık, alıcı kelime hazinesi, beden dili, eklemleme (artikülasyon) ve gürültü kavramlarının öne çıktığı görülmektedir. Dinleme sürecinde yüzey yapıdan derin yapıya ilerleyen bir süreç vardır.

Temel dil becerilerinin eğitiminde yüzey yapı ve derin yapı süreçlerinin birbirinden ayrı düşünülmesi gerekmektedir. Yukarıda sıralanan kavramların, temel dil becerilerinin oluşumunda, derin yapı ve yüzey yapı süreçleri üzerinde ayrı ayrı etkili oldukları söylenebilir.

Akıcılık, kelime hazinesi ve ön bilgi kavramlarının bütün temel dil becerilerinin eğitiminde etkili olduğu görülmektedir. Yüzey yapı derin yapı ilişkileri bağlamında en fazla değişken içeren temel dil becerisi okumadır. Bu kavramlar arasında boğumlama, bürün olgusu, beden dili, akıcılık, bağdaşıklık, metin türü, kelime tanıma, kelime ayırt etme, yazım ve noktalama, doğrudan yüzey 
yapıyla ilgilidir. Üretici kelime hazinesi, alıcı kelime hazinesi, tutarlılık, ön bilgi, edinilmiş bilgi, önvarsayım ve sezdirim kavramları ise derin yapıyı ilgilendirmektedir.

Sonuç olarak boğumlama, bürün olguları, beden dili, alıcı kelime hazinesi, üretici kelime hazinesi, akıcılık, ön bilgi, yazım ve noktalama, metin türünün seçimi, bağdaşıklık, tutarlılık, kelime tanıma, kelime ayırt etme, edinilmiş bilgi, önvarsayım, sezdirim, eklemleme ve gürültü kavramlarııın ana dili eğitimi çerçevesinde temel dil becerilerinin eğitiminde göz önüne alınması, bu hususlarla ilgili uygulama örneklerine ders kitaplarında ve sınıf içindeki çalışmalarda öncelik verilmesi gerekmektedir.

\section{Kaynakça}

Akyol, H., (2005). Türkçe ilk okuma yazma öğretimi. Ankara: Pegem Akademi Yayıncılık. Demirci, K., (2013). Türkoloji için dilbilim. Ankara: Anı Yayıncılık.

Dilâç̧ar, A., (1968). Dil, diller, dilcilik. Ankara: Türk Dil Kurumu Yayınları.

Ergenç, İclâl., (1989). Türkiye Türkçesinin görevsel sesbilimi. Ankara: Engin Yayınevi.

Göğüş, B., (1978). Orta okullarda Türkçe ve yazın eğitimi. Ankara: Gül Yayınevi.

Gökşen, E.N., (1967). Noktalama işaretlerinin dünü bugünü. Dil bilgisi Sorunları, Ankara: Ankara Üniversitesi Basımevi, 105-113.

Günay, D., (2003). Metin bilgisi. İstanbul: Multilingual Yayınları.

Güneş, F., (2007). Türkçe öğretimi ve zihinsel yapılandırma. Ankara: Nobel Yayın Dağııım.

Hengirmen, M., ve Güler, E. (2005). Ses bilimi ve diksiyon. Ankara: Engin Yayınevi.

Karadağ, Ö., (2013). Kelime öğretimi. İstanbul: Kriter Yayınları.

Karataş, T., (2004). Ansiklopedik edebiyat terimleri sözlüğü. Ankara: Akçağ Yayınları.

Kaya, A., (2010). iletiş̧ime giriş: temel kavramlar ve süreçler. Kişilerarası ilişkiler ve etkili iletişim. Ankara: Pegem Akademi.

Kıran, Z., (2001). Dilbilime giriş. İstanbul: Seçkin Yayıncılık.

Korkmaz, Z., (1992). Gramer terimleri sözlüğü. Ankara: Türk Dil Kurumu Yayınları.

Onan, B. ve Tiryaki E.N. (2012). Türkçede örtülü anlam oluşturan unsurlar ve ana dili öğretimindeki işlevleri. Mustafa Kemal Üniversitesi Sosyal Bilimler Enstitüsü Dergisi. 9(19), 223-240.

Onan, B., (2006). Ses olgusunun denetlenebilirliği bağlamında dil becerilerinin geliştirilmesinde etkili olduğu düşünülen fonolojik yönlendiriciler. Türklük Bilimi Araştırmaları Dergisi. 20, 141-163.

Onan, B., (2013). Dil eğitiminin temel kavramları. Ankara: Nobel Yayınevi.

Önen, A., (2004). Türkçeyi Türkçe konuşmak. İstanbul: İnkılap Kitabevi.

Özbay, M., (2009). Türkçe özel öğretim yöntemleri ii. Ankara: Öncü Kitap.

Özgür, i., (2006). Konuşma bozukluğu ve sağlatımı. Adana: Nobel Kitabevi.

Rifat, M., (1998). 20. yüzyılda dilbilim ve göstergebilim kuramları i. İstanbul: Yapı Kredi Yayınları

Temur, T., (2001). Dinleme becerisi, Konu Alanı Ders Kitabı Inceleme Kılavuzu Türkçe 1-8. Ankara: Nobel Yayınları.

Toklu, O., (2003). Dilbilime giriş. Ankara: Akçağ Yayınları.

Vardar, B., (2003). Açıklamalı dilbilim terimleri sözlüğü. ìstanbul: Multılıngual Yayınları

Yalçın, A., (2002). Türkçe öğretim yöntemleri. Ankara: Akçağ Yayınları. 